\author{
Ю. А. ШАШКО ${ }^{1,2}$, О. В. КУЛИК ${ }^{1}$ Р. Ф. МАКСИМЧУК ${ }^{2}$, А. Ф. САНІН \\ 1 Дніпровський національний університет імені Олеся Гончара, Дніпро, Украӥна \\ ${ }^{2}$ Flight Control Propulsion, Дніпро, Украӥна
}

\title{
ВИБІР ОПТИМАЛЬНИХ МЕТОДІВ ЧИСТОВОЇ ОБРОБКИ ЛОПАТОК ЗАКРИТИХ МОНОКОЛІС ТУРБОНАСОСНИХ АГРЕГАТІВ, ОТРИМАНИХ АДИТИВНИМ МЕТОДОМ ПРЯМОГО ЛАЗЕРНОГО СПІКАННЯ ПОРОШКУ
}

\begin{abstract}
Створення складних конструкційних елементів літальних апаратів з використанням є перспективним та набуває широкого застосування, оскільки такі елементи мають ряд конструктивних та технологічних переваг в порівнянні зі виготовленням деталей за класичними технологіями. Однак воно потребує вирішення ряду науково-технічних завдань для отримання виробів високої точності і шорсткості, розробку технологічного прочесу, відпрацювання режимів обробки, а інколи і розробки нової конструкиії виробів. Для сприяння розвитку технологій у сучасному ракетобудуванні, підвищення якості та точності виробництва турбін турбонасосних агрегатів важливим завданням є пошук нових та вдосконалення існуючих технологічних рішень для виготовлення подібних деталей з високою якістю поверхні. Метою роботи був аналіз існуючих методів обробки деталей турбонасосних агрегатів зі складною геометрією та обрання найбільш технологічного задля подальшого використання у технологічних процесах. Завданням даної статті є аналітичний огляд існуючих методів обробки поверхні деталей відповідального призначення та вибір найбільш технологічного при чистовій обробиі лопаток турбіни закритого типу (з бандажем), з метою зниження шорсткості та покращення якості робочої поверхні. Об'єктом дослідження є процес обробки сегменту робочого колеса турбіни із нікелевого сплаву Inсопеl 718 (вітчизняний аналог - сплав ХН45МВТЮБР), щчо є ключовим елементом турбонасосного агрегату. Заготовка деталі типу «моноколесо» турбіни була виготовлена за допомогою технологї $3 D$-друку. У підсумку роботи було обрано оптимальний метод обробки, а саме - технологію сухого електрохімічного полірування DryLyte, щзо має досить значні переваги в порівнянні з алогічними методами. Даний метод пройшов експериментальне відпрацювання і активно впроваджується за кордоном. Для впровадження даної технології DryLyte необхідно провести додаткові експерименти по чистовій обробиі внутрішніх каналів невеликого розміру (24 мм) на прикладі міжлопаткових каналів турбін, щзо дасть змогу повною мірою оцінити можливості технології.
\end{abstract}

Ключові слова: технологічність; турбонасосний агрегат; моноколесо; адитивні технологї; SLM; якість, шорсткість, лопатки.

\section{Вступ}

До роторів турбін турбонасосних агрегатів висуваються особливо високі вимоги за точністю обробки, якістю та шорсткістю поверхонь.

На сьогоднішній день існує широка номенклатура деталей зі складнопрофільними поверхнями, обробка яких традиційними методами ускладнена або навіть неможлива.

До таких деталей відносяться закриті робочі колеса турбін турбонасосних агрегатів (ТНА) рідинних ракетних двигунів (РРД).

Матеріал диску турбіни та лопаток повинен задовольняти ряд технологічних вимог: володіти достатньою жаростійкістю, добре зварюватися та оброблятися різанням, а також конструктивним вимогам: працювати у високотемпературному середовищі корозійно-активних газів, важливо також зберігати високу міцність і надійність [1].

На рис.1. зображено моноколесо, що було виготовлено методом SLM Selective Laser Melting селективне лазерне плавлення 3 порошку жароміцного сплаву на основі нікелю Inconel 718.

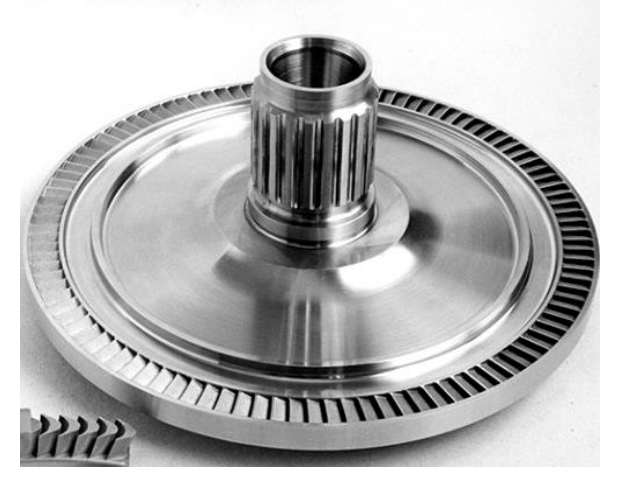

Рис. 1. Моноколесо ТНА

(C) Ю. А. Шашко, О. В. Кулик, Р. Ф. Максимчук, А. Ф. Санін, 2021 
Традиційно виготовлення таких деталей забезпечується використанням освоєних наукомістких технологій виготовлення таких як штампування, зварювання та лиття по витоплюваним моделям із залученням спеціального технологічного обладнання, пристосувань і працівників високої кваліфікації, а також використання традиційного довготривалого циклу виробництва. Враховуючи дрібносерійне, а подекуди одиничне, виробництво та виготовлення подібних деталей традиційними методами собівартість одиниці зростає.

В умовах одиничного та дрібносерійного виробництва широкого застосування у ракетно-космічній галузі набувають адитивні технології, які за якістю виготовленої продукції не поступаються традиційним методам. Не дивлячись на те, що 3D-друк вимагає використання складного наукомісткого, високовартісного обладнання, даний метод має ряд переваг що дозволяс спростити та прискорити процес виготовлення $з$ мінімальним припуском на обробку та меншою собівартістю деталей. 3D-друк має ряд значних переваг: покращені властивості готової продукції, велика економія сировини, можливість виготовлення виробів зі складною геометрією, мобільність виробництва, прискорення обміну даними, тощо [2].

Однак, не дивлячись на ці переваги, залишається проблема шорсткості поверхонь, особливо нависаючих елементів деталей таких, як перо лопатки. В роботі [6] в результаті дослідження було виявлено, що шорсткість поверхні залежить від ії положення в робочому просторі при друкові та не залежить від форми. Найменшу шорсткість вдалося отримати на вертикальних поверхнях $-\mathrm{R}_{\mathrm{a}}=1,6 \ldots 2,5$. Чим більше поверхня відхиляється від вертикалі, тим більша шорсткість. На горизонтальних поверхнях вона може досягати до $\mathrm{R}_{\mathrm{z}}=40 \ldots 50$. Необхідна шорсткість лопаток для забезпечення надійної роботи турбіни та необхідних характеристик становить Ra 0,63 [3].

Тому забезпечення належної якості поверхонь закритих лопаток залишається актуальною проблемою по причині ускладненого, а подекуди, неможливого доступу інструменту до оброблюваної поверхні.

Аналіз останніх досліджень. Для сприяння розвитку технологій у сучасному ракетобудуванні, підвищення якості та точності виробництва турбін турбонасосних агрегатів є важливим завданням пошук нових та вдосконалення існуючих технологічних рішень для виготовлення подібних деталей 3 високою якістю поверхні.

Автором роботи [4] було зазначено, що від шорсткості поверхні залежить якість наступних операцій, таких як: термічна обробка, нанесення захисних плівок та покриттів, тощо.
Тому забезпечення належної якості поверхонь закритих лопаток залишається актуальною проблемою по причині ускладненого, а інколи - неможливого доступу інструменту до оброблюваної поверхні [5].

Деякі особливості геометрії деталей (краї що звисають, похилі поверхні, тонкі стінки, ажурні конструкції, змінний переріз, отвори) вимагають спеціальних умов обробки поверхонь для забезпечення заданої кресленням та технологічними вимогами шорсткості [6].

\section{Аналіз існуючих методів обробки моноколіс}

Електроерозійна обробка. Одним 3 найбільш освоєних методів обробки подібних деталей є електроерозійна обробка профільними електродінструментами. Серед недоліків даного методу, крім високої вартості та тривалості обробки, слід зазначити складність виготовлення комплекту профільних електродів (для чистової та чорнової обробки), складність налаштування обладнання при непарній кількості лопаток, наявність дефектного шару металу після обробки та зони переходу електродінструментів на лопатці.

Електроерозійний метод (ЕЕО) отримав широке застосування для чорнової та чистової обробки міжлопаткових каналів. Цей метод заснований на вириванні частинок матеріалу з поверхні імпульсом електричного розряду. Під впливом високих температур у зоні розряду відбувається нагрів, розплавлення і часткове випаровування металу. Процес електроерозійної обробки відбувається в робочій рідині, яка заповнює простір між електродами, при цьому один з електродів - заготовка, а інший електрод - інструмент. Механізм процесу наведений на рис. 2.

До основних переваг цього способу обробки можна віднести: можливість обробки будь-яких струмопровідних матеріалів незалежно від їх фізико-хімічних властивостей, твердості, в'язкості і крихкості; забезпечення обробки заготовки одночасно по всій складній поверхні 3 мінімальною шириною зрізу за рахунок поступального переміщення електрода-інструменту, що має на торці необхідний профіль оброблюваної поверхні; технологічні операції практично виконуються без силового впливу інструменту на заготовку, що дозволяє обробляти поверхні нежорстких і тонкостінних деталей; можливість одночасного обслуговування одним оператором декількох верстатів, так як електроерозійні верстати, як правило, $є$ верстатами - напівавтоматами і автоматами. 
Процес ЕЕО супроводжується високою температурою та великою концентрацією енергії в зоні обробки, що в свою чергу сприяє зниженню фізикомеханічні характеристики поверхневого шару , тому дані методи енергозатратні і малопродуктивні, що підвищує собівартість осьових моноколіс [7].

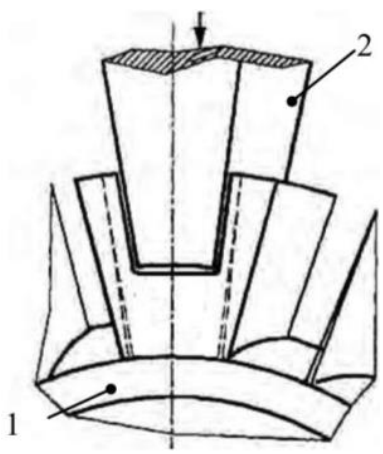

a

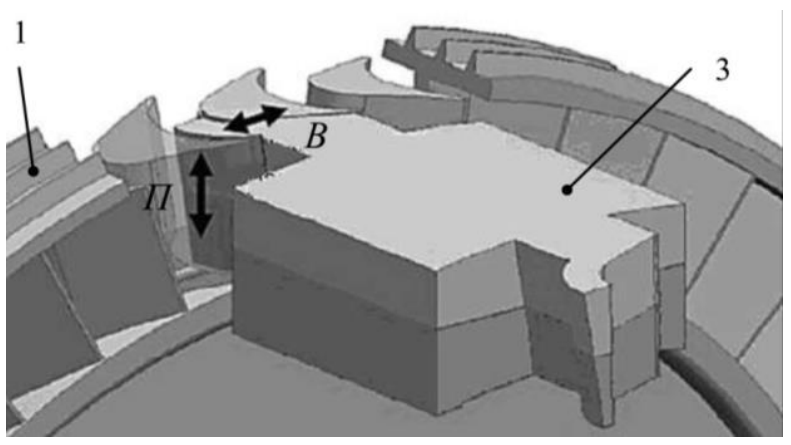

6

Рис. 2. Електрохімічна обробка:

1 - деталь; 2, 3 - електрод; а - спеціалізованим інструментом; б - універсальним інструментом

(П - оброблювана поверхня лопатки;

В - відстань між лопатками)

Магнітно-абразивна обробка. Магнітно-абразивна обробка грунтується на властивостях магнітного поля впливати на феромагнітні частинки 3 силою, достатньою для вибіркового абразивного впливу на поверхню змінного профілю. Однією з переваг $\epsilon$ те, що у поверхневих шарах деталі після такої обробки, формуються залишкові стискаючі напруження незалежно від вихідних успадкованих напружень від попередніх технологічних операцій. Формування залишкових стискаючих напружень в поверхневих шарах лопатки запобігає появі мікротріщин та сповільнюють їх утворення, і відповідно збільшують ресурс роботи. Недоліком магнітно-абразивної обробки є неможливість рівномірного знімання металу 3 оброблюваної просторової поверхні, і поверхні міжлопаткових каналів [8].

Віброабразивна обробка. Широкого застосування набув метод вібраційної обробки, який, в свою чергу, поділяється на віброабразивну та віброударну обробки . Віброударна обробка використовується для зміцнення поверхні, а віброабразивна для зняття задирок та припусків, притуплення гострих кромок, очищення поверхні складної форми, полірування тощо. Схеми і параметри реалізації процесу для цих двох способів майже аналогічні. Відмінності полягають у використанні різних видів робочих тіл. При віброударній обробці - це загартовані сталеві кульки, дріб та інші металеві елементи. При віброабразивній обробці в якості інструменту застосовуються абразивні гранули різної форми, складу і розмірів, а самі деталі в контейнері в більшості випадків не закріплюють.

Для проведення обробки на контейнер, що змонтований на пружних підвісках, накладаються низькочастотні коливання за допомогою дебалансного вібратора або електромагнітних пристроїв i надають можливість коливатися в різних напрямках. У результаті низькочастотних вібрацій середовище обробки та деталі перебувають в постійному русі щодо один одного і роблять два види переміщень: коливання, синхронні з частотою коливань контейнера, і колові перемішування всього обсягу завантаженої маси .

Змінюючи фізичні властивості та розміри гранул, моделюючи характер вібрацій, можна успішно обробляти як зовнішні поверхні, так і внутрішні порожнини деталей складної форми. Вібраційна обробка має ряд істотних недоліків. У першу чергу це слабкі енергетичні та техніко-економічні показники. Віброобертальні пристрої володіють значним ресурсом роботи і великою вантажопідйомністю, але працюють на віброприскореннях не більш $15 \ldots 20 \mathrm{~g}$ та віброшвидкості 1,0 ..1,3 м/с. 3 цієї причини віброобробка має досить тривалий цикл, часто до 2-3 годин.

Ще одним недоліком цього способу є неможливість обробити локальну ділянку на поверхні. Віброабразивна обробка являє собою безрозмірну схему з незакріпленим абразивом, це призводить до підвищення часу і витрат енергії на обробку кожної деталі. До того ж, такий спосіб досить ефективний при обробці важкодоступних, але просторих внутрішніх поверхонь корпусів, але даний метод не дозволяє здійснювати обробку малогабаритних внутрішніх поверхонь [9].

Абразивна екструзія. Метод екструзії полягає в прокачуванні суміші каучуку з абразивом через канали деталі, але при цьому відбувається нерівномірне знімання матеріалу, якщо деталь має змінний перетин каналу. Продуктивність зростає в міру звуження каналу і знижується в напрямку його розширення (рис. 3). 


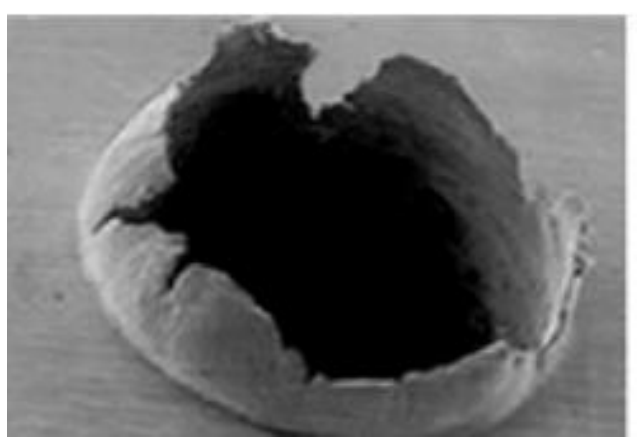

a

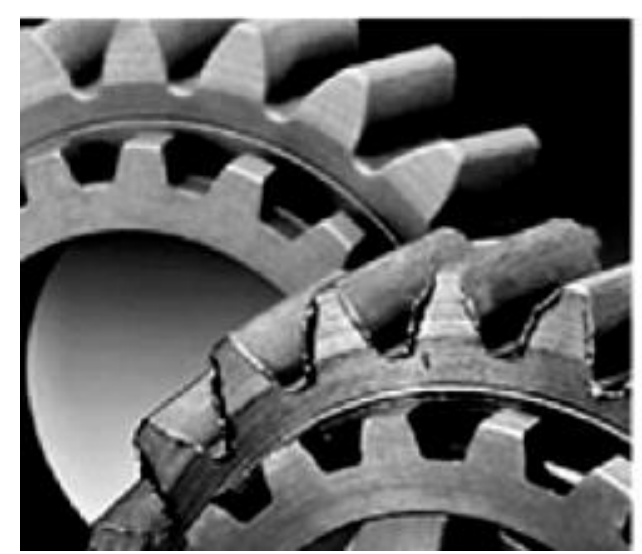

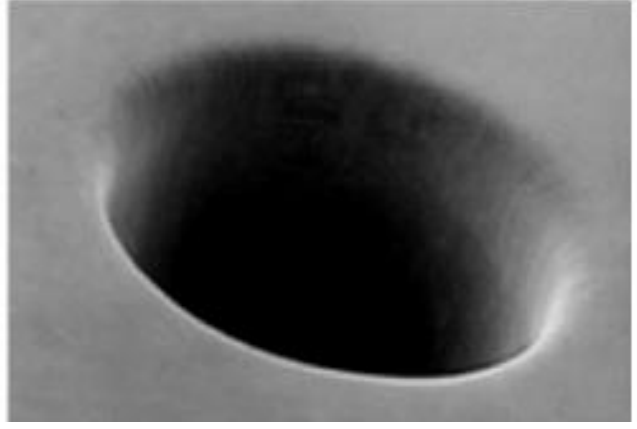

6

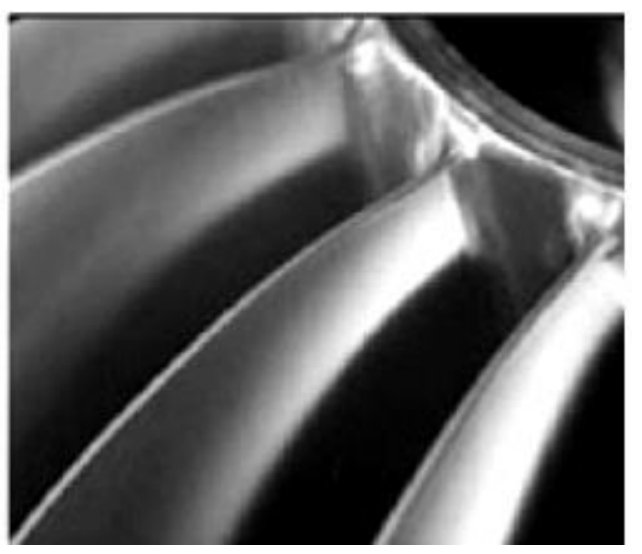

B

Рис. 3. Ілюстрація ефективності екструзійно-абразивної обробки: а - видалення заусенців на вихідних отворах;

б - видалення заусенців та чистова обробка; в - поверхня лопаток моноколеса

Увесь процес екструзії обробки деталей полягає в тому, що абразивна суміш проштовхується вздовж оброблюваної поверхні по осі каналу. Розвиток і модернізація методу екструзії обробки направлено на збільшення області його використання. Так, застосування на установці для екструдування спеціальних напрямних пристроїв дозволяє трохи подовжити канал і направити абразивну суміш під кутом до траєкторії іiі просування, забезпечуючи обробку каналу конусної форми.

Але все одно екструзійна обробка складно профільних каналів відбувається нерівномірно і досягає максимальних значень у найбільш вузькому перерізі. Необхідну нам рівномірну шорсткість даний спосіб забезпечити не може [10].

Турбоабразивна обробка. Дозволяє ефективно видаляти задирки після практично всіх операцій механічної обробки деталей різної форми. Це забезпечується за рахунок великої частоти зіткнень абразивних зерен з деталлю, що обробляється. Інтенсивність зіткнень призводить до обламування і стирання задирок за дуже короткий час. Знімання металу відбувається і за рахунок мікрорізання при мікроударах абразивних зерен об поверхню деталі. Сутність методу полягає у тому, що цей процес відбува- ється при незначному нагріванні деталі від тертя і невантаженому обкатуванні деталі в середовищі «підвішених» абразивних зерен. У порівнянні з традиційною зачисткою така обробка гарантовано знижує шорсткість поверхні до Ra 0,32...0,63.

Одним з перспективних методів абразивної обробки є планетарно-ротаційний.

Метод обробки деталей складної форми заснований на ефекті псевдозрідження сипучих матеріалів і характеризується створенням «кипіння» шару абразиву. У нього опускають деталь, що обробляється відповідно до ії форми задають робочий обертальний або планетарний рух. Швидкість обертання становить не більше 30 м / с. Реалізація ефекту «кипіння» шару абразиву відбувається наддувом стисненого повітря. Виробнича апробація показує, що час повного видалення задирок на деталях з різних матеріалів (від кольорових металів до конструкційних сталей, титанових і жароміцних сплавів) становить від 3 до 15 хвилин.

Також така обробка формує мікрорельєф поверхонь, що забезпечує відмінні адгезійні характеристики обробленої поверхні (в тому випадку, коли планується нанесення жаростійкого покриття). Реа- 
лізація процесу турбоабразивної обробки найбільш ефективна для відкритих поверхонь [11].

Піскоструменева обробка. Широко використовується технологія піскоструменевої обробки обдув оброблюваної поверхні стиснутим повітрям 3 додаванням абразивних матеріалів, серед переваг даного методу це простота використання обладнання і екологічність. Однак даний метод має суттєві недоліки. У залежності від стану оброблюваної поверхні розмір абразивних зерен обирається в межах $0,25 \ldots 2$ мм, робочий тиск повітря при обробці $0,6 \ldots 1,2$ МПа . Основним і вагомим недоліком даного методу є складність контролю обробки точних та тонкостінних деталей [12].

Гідроабразивна обробка (ГАО). Метод гідроабразивної обробки є одним з найбільш ефективних, екологічно чистих та енергозберігаючих технологій обробки, що застосовуються для розкрою листового матеріалу, при прорізанні пазів (рис. 4, б), вікон, прошивці отворів, зачищення та полірування зовнішніх і внутрішніх поверхонь складного профілю, у тому числі і в важкодоступних місцях виробів, маркування та гравірування. При гідроабразивній обробці (див. рис. 4) у водоструменевих установках насосом високого тиску створюється високий тиск води (близько 400 МПа), який перетворюється в кінетичну енергію струменя, яка витікає через змішувальні трубки сопла. У процесі обробки сопло переміщується по відношенню до непрофільованої заготовки.

Концентрація абразиву в суміші становить від 20 до 40\%. Додавання інгібіторів корозії у воду запобігає утворенню корозії на оброблюваних поверхнях, потік суспензії доповнюється струменем стисненого повітря, що трохи підвищує швидкість струменя суспензії. Після такої обробки отримують очищені матові поверхні без характерних для традиційних методів механічної обробки різноспрямованих рисок і задирів. Вплив гострих поверхонь абразивних зерен на оброблювану поверхню має короткочасний і імпульсно-ударний характер. Це і $є$ основа ефективності процесу. Режими абразивнорідинної обробки можна змінювати в широких межах у залежності від видів абразивів, їх параметрів, співвідношення абразиву і води, швидкості потоку і відстані між зрізом сопла і поверхнею, кута контакту потоку з оброблюваною поверхнею і конструкцією розпилювача сопла [13].

Основні недоліки гідроабразивної обробки: порівняно малий термін служби змішувальних трубок (до 50 год. роботи); складність управління процесом обробки, обумовленого специфікою взаємодії струменя і оброблюваного матеріалу, низька точність, низька якість отриманих поверхонь міжлопаткового каналу (див. рис. 4) та складність контролю процесу обробки. Використання методу гідроабразивної обробки для підвищення продуктивності попереднього прорізання міжлопаткового каналу не став успішним. Однак, дана технологія може використовуватися не тільки для розкрою матеріалів та прорізання пазів.
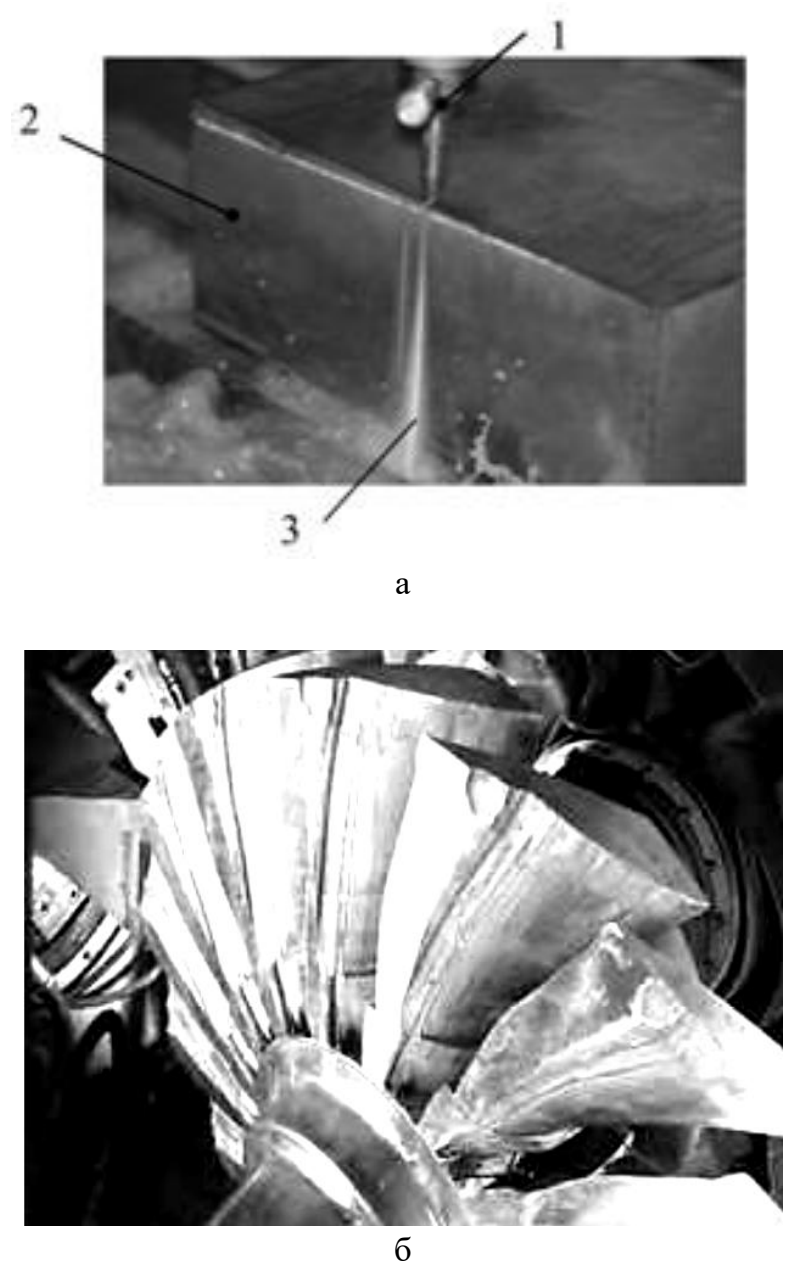

Рис. 4. Гідроабразивна обробка міжлопаткових каналів осьових моноколіс: a - приклад обробки; 1 - змішувальна трубка сопла; 2 - оброблювана заготівка; 3 - гідроабразивний струмінь; б - осьове моноколесо після гідроабразивної обробки

На відміну від піскоструменевої обробки при ГАО можливе використання в якості абразиву шліфувальних та мікрошліфувальних порошків. Розміри абразивних частинок залежно від призначення операції обирають в межах $300 \ldots 7$ мкм. Проведені дослідження показують, що технологія ГАО дозволяє отримувати поверхні виробів 3 шорсткістю менше Ra 0,5 мкм.

При обробці поверхні мікро-шліфувальними порошками показники якості поверхні можна визнати ідентичними аналогічними показникам напівчистового шліфування. 
Вплив технологічних факторів процесу ГАО на показники якості обробленої поверхні заготовок з різних матеріалів, оцінка геометричних параметрів поверхні, обгрунтування оптимальних технологічних режимів вивчалися у роботах.

Результати показують що продуктивність процесу обробки залежить більшою мірою від зернистості абразиву, кута обробки, твердості оброблюваного матеріалу, взаємного переміщення сопла відносно заготівки та рівномірності обробки.

Однак, для визначення оптимальних параметрів процесу та прямої залежності між ними актуальною проблемою є забезпечення необхідної концентрації абразивного матеріалу, що є основним фактором забезпечення необхідної шорсткості та форми поверхні [14].

Галтування - безрозмірна обробка деталей 3 метою заусенців та облою, заокруглення гострих кромок, зняття окалини та ржавчини, отримання заданої шорсткості обробленої поверхні, полірування. Галтування використовується у випадках, коли необхідно обробити велику кількість однотипних деталей 3 досягненням заданої якості поверхні та зменшенням ручної праці. Основними параметрами галтування є частота обертання барабана та тривалість обробки. Однак крім цього перед початком процесу варто визначити тип і розмір абразивного наповнювача (галтовочних тіл), тип технологічної рідини, їх співвідношення та концентрацію.

В умовах серійного і дрібносерійного виробництва, коли необхідно у найкоротші терміни виконати галтовку невеликих партій різних виробів, єдиним методом визначення найбільш оптимального абразивного наповнювача являється безпосередній практичний досвід. Підбір наповнювача в процесі роботи має ряд недоліків, серед яких тривалість процесу, непередбачуваність результату та висока вірогідність браку деталей.

У випадку обробки малих партій деталей, які раніше не оброблялися на підприємстві та для яких неможливо спрогнозувати терміни наступного виготовлення (одиничні замовлення на вироби для ремонтного обслуговування), наповнювач підбирається по аналогії з опрацьованими раніше однотипними деталями. Розмір і форма абразиву значно впливає на продуктивність процесу.

За загальним правилом, розмір абразивного наповнювача повинен бути таким , щоб він не застрягав у пазах, поглибленнях і отворах деталей. Даний метод потребує більш детального вивчення і великої експериментальної бази [15].

Шліфування абразивними стрічками. Стрічки зазвичай вкриті абразивними зернами або пастами. Цей метод $є$ більш досконалим, ніж полірування за допомогою абразивних кругів.
Шліфування та полірування абразивними стрічками є поширеним методом при шліфуванні (плоскому, круглому і безцентровому), чорновій та чистовій обробці деталей, при зачистці поковок, виливків, труб та листового матеріалу. Використовується обробка абразивними стрічками замість ручної обробки при виконанні слюсарних робіт і при доведенні деталей складної форми. Переважно полірування абразивною стрічкою забезпечує зниження шорсткості поверхні без зміни геометричної форми і розмірів деталі. Стрічкове шліфування має ряд переваг в порівнянні з обробкою абразивними колами: збільшений контакт між стрічкою і деталлю, яка обробляється; мінімальна температура у зоні контакту з поверхнею; участь в процесі обробки відразу великої кількості зерен за один оберт стрічки, однотипна шорсткість поверхні, можливість машинного шліфування та інше.

До недоліків варто віднести: розтягнення стрічки в процесі роботи, неможливість досягнення високої точності форми і розмірів, порівняно невисока стійкість стрічки і малий термін служби через неможливості її корегування.

Неможливість використання шліфувальних стрічок, у випадку моноколіс, обумовлена не тільки конструктивними особливостями, але і характером обробки, який не забезпечує повного контакту стрічки 3 оброблюваною поверхнею. Даним методом можлива часткова обробка спинок лопаток (верхньої частини), а шліфування жолоба взагалі технологічно не можливе [11].

Сухе електрохімічне полірування. У кінці 2017 року була представлена унікальна технологія фінішної обробки поверхні - DryLyte.

DryLyte - це технологія сухого електрохімічного шліфування та полірування металевих виробів шляхом перенесення іонів металу за допомогою вільних твердих тіл (рис. 5). Відмінною особливістю та унікальністю DryLyte $\epsilon$ те, що рідини не використовуються в якості електролітів. Також на відміну від традиційного способу полірування, обробка технологією DryLyte зберігає початкові форми виробів, включаючи кути та ріжучі кромки. В процесі сухого електрохімічного полірування відбувається процес об'ємного шліфування та полірування, при якому обробляється вся поверхня деталі незалежно від іiі геометрії.

При обробці матеріал видаляється тільки 3 максимально шорстких поверхонь

Технологія DryLyte забезпечує дзеркальну поверхню високої якості, обробку за один крок i, що найважливіше, дозволяє попередньо розрахувати затрати.

Завдяки даній технології вдалося досягти шорсткості поверхні виробів на рівні Ra 0,08 мкм. 


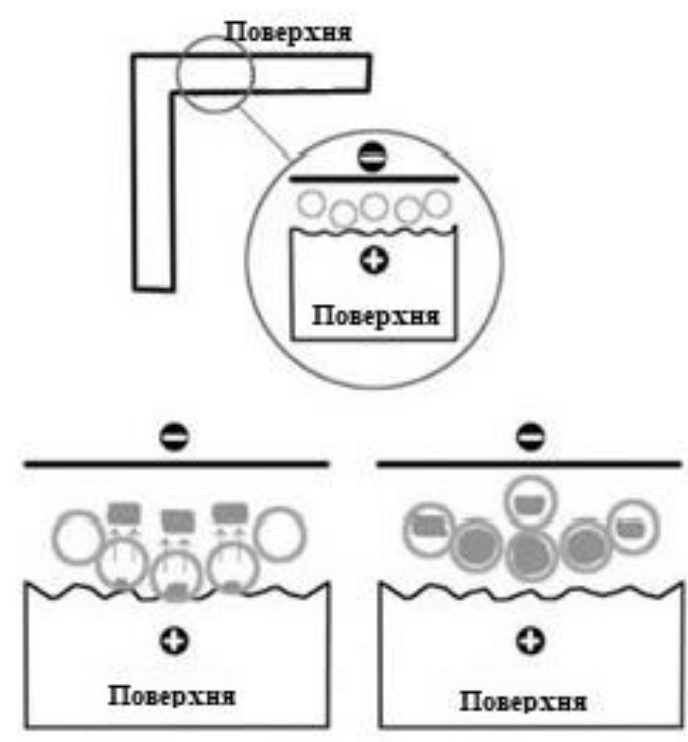

Рис. 5. Схема дії технологї сухого електрохімічного шліфування

Раніше при ручному поліруванні не можна було навіть наблизитись до таких показників.

У роботі деяких авторів [10] наведений приклад оптимізації виробництва завдяки технології DryLyte, це дозволило скоротити час обробки в перерахунку на одиницю часу виробу більш ніж у 5 разів. Зменшилась у 3,36 рази вартість полірування одиниці виробу. Таким чином, виробничий цикл суттєво скоротився, а продуктивність виросла. Це посприяло впровадженню додаткової лінійки виробів більш дешевого цінового діапазону. У результаті зробленої роботи був отриманий повністю автоматизований, а найважливіше, прогнозований процес полірування, стандартна якість якого незалежна від кількості деталей в партії.

Технологія DryLyte - це універсальний інструмент для фінішної обробки і підходить як для полірування дрібних виробів ювелірного типу, так і для партій крупногабаритних виробів, на прикладі лопаток турбін.

\section{Висновки}

Аналізуючи данні наукових робіт авторами було зроблено такий висновок:

1. Враховуючи особливості конструкції моноколеса закритого типу, складність доступу інструменту до закритих поверхонь та особливості оброблюваного матеріалу, існує необхідність у пошуку найбільш оптимального методу або комбінації методів для забезпечення кінцевої якості поверхні.

2. Результати аналізу існуючих методів та нових технологічних рішень обробки доводять, що такі методи як електроерозійна та електрохімічна обробка втрачають свою актуальність. Основною причиною цього $є$ високі енергозатрати обробки, не всі існуючі технологічні підходи дозволяють повною мірою забезпечити необхідну кінцеву якість поверхні. Кожному з методів властиві переваги та деякі недоліки, що обмежують їх застосування.

3. Дещо більшу перспективу мають методи екструзійно-абразивної, турбоабразивної обробки та комбінованої електричної обробки. Однак ці методи потребують детальнішого експериментального відпрацювання для визначення режимів обробки та застосування того чи іншого методу для певної геометрії.

4. Менш перспективними є галтування та електроерозійна обробка. Обробка нежорстких деталей або $з$ нежорсткими елементами не рекомендується. Електроерозійна обробка не зважаючи на найбільше поширення та застосування є енергоємним, дорогим методом що має велику тривалість обробки, потребує складного оснащення і залежить від обробки типу та конструкції моноколеса.

5. Перспективним напрямком $є$ застосування технології сухого електрохімічного полірування DryLyte , що має досить значні переваги в порівнянні $з$ вітчизняними методами. Даний метод пройшов експериментальне відпрацювання і активно впроваджується за кордоном. Для впровадження даної технології DryLyte необхідно провести додаткові експерименти по чистовій обробці внутрішніх каналів невеликого розміру (24 мм) на прикладі міжлопаткових каналів турбін, що дасть змогу повною мірою оцінити можливості технології.

На нашу думку DryLyte заслуговує подальшого вивчення 3 перспективою використання при виробництві вітчизняних деталей ракетно-космічної техніки.

\section{Література}

1. Тихонов, Н. Т. Теория лопаточных машин авиационных газотурбинных двигателей [Текст] / Н. Т. Тихонов, Н. Ф. Мусаткин, В. Н. Матвеев. Самара : Самарский государственный аэрокосмический университет, 2001. - 155 c.

2. Моргунов, Ю. А. Аддитивные технологии для авиакосмической техники [Текст] / Ю. А. Моргунов, Б. П. Саушкин // Аддитивные технологии. 2016. - T. 1, № 1. - C. 30-38.

3. Аджамский, С. В. Перспективы применения аддитивных технологий в авиа- и ракетостроении [Текст] / С. В. Аджамский, А. А. Кононенко, Р. В. Подольский // Авіаційно-космічна техніка $і$ технологія. - 2020. - № 7 (167). - C. 59-65. DOI: 10.32620/aktt.2020.7.09 
4. Kaynak, Y. Post-processing effects on the surface characteristics of Inconel 718 alloy fabricated by selective laser melting additive manufacturing. [Text] / Y. Kaynak, E. Tascioglu // Progress Additive Manufacturing. - 2020. - Vol. 5. - P. 221-234. DOI: 10.1007/s40964-019-00099-1.

5. Rudawska, Anna. Surface Treatment in Bonding Technology [Text] / Anna Rudawska. - Faculty of Mechanical Engineering, Lublin University of Technology, Lublin, Poland, 2019. - 284 p. DOI: 10.1016/C2018-0-01281-5.

6. Andreas, W. Hydroblasting and Coating of Steel Structures [Text] / W. Andreas. - Elsevier Science, 2003. - 205 p. DOI: 10.1016/B978-1-85617-3957.X5000-8.

7. Electrode feeding path searching for 5-axis EDM of integral shrouded blisks [Text] / X. Liu, X. Kang, W. Zhao, W. Liang // Procedia CIRP. - 2013. - Iss. 6. - P. 107-111.

8. K вопросу выбора технологии обработки сложнопрофильных изделий (на примере лопаток моноколес газотурбинных двигателей) [Текст] / В. А. Горелов, С. В. Аршинов, Ю. В. Максимов, Б. Е.Пини, А. А. Бекаев, В.Г. Мерзликин, А. Ю. Второва // Известия Моск. госуд. техн. ун-та МАМИ. -2012. - Том. 2, № 2 (14). - С. 67-73.

9. Influence of Threshold Based Process Control on Sinking EDM of a High Aspect Ratio Geometry in a Gamma Titanium Aluminide [Text] / F. Klocke, M. Holstena, D. Welling, A. Klink, R. Perez // Procedia CIRP. - 2015. - Iss. 35. - P. 73-78. DOI: 10.1016/j.procir.2013.03.041.

10. Разработка и применение новых методов упрочнения деталей ГТД, основанных на пластическом деформировании поверхностных слоев [Текст] / Ю. А. Ножницкий, А. В. Фишгойт, Р. И. Ткаченко, С. В. Теплова // Вестник двигателестроения. - 2006. - № 2. - C. 8-16.

11. Технологии производительного формирования комбинированными методами поверхностей полостей и каналов под нанесение защитных покрытий [Текст] / Г. А. Сухочев, Е. Г. Смольянникова, С. Н. Коденцев, Д. М. Небольсин // Упрочняющзие технологии и покрытия. - 2009. - № 11(59). C. 49-54.

12. Обработка поверхности струйными методами [Текст] / С. Н. Полянский, С. В. Бутаков, В. А. Александров, И. С. Ольков // Аграрный вестник Урала. -2015. - № 12(142). -С. 43-47.

13. Шпилев, В. В. Влияние факторов гидроабразивной резки на шероховатость обработанной поверхности, ее твердость, овальность и конусообразность [Текст] / В. В. Шиилев, М. К. Решетников // Вестник. Саратовского государственного технического. университета. - 2011. - T. 2, № 2. - С. 160 163.
14. Тарасов, В. А. Оценка геометрических параметров формируемой поверхности при гидроабразивной обработке [Текст] / В. А. Тарасов, А. Н. Полухин // Вестник МГТУ им. Н. Э. Баумана. Сер. «Машиностроение». - 2012. - № 1. - С. 107 116.

15. Определение геометрической точности $u$ шероховатости поверхности малогабаритных деталей круглого и квадратного сечения, получаемых 8 зависимости от расположения в рабочем пространстве принтера по технологии селективного лазерного плавления из стали марки 12 X18Н10Т [Текст] / И. В. Горбатов, Ю. А. Орлов, В. А. Антюфев, Т. В. Тельгерекова, Н. Ю. Орлова // Вестн. Кониерна ВКО «Алмаз - Антей». - Москва, 2019. Bbin. 1. - C. 59-67.

\section{References}

1. Tikhonov, N. T., Musatkin, N. F., Matveev, V. N. Teoriya lopatochnykh mashin aviatsionnykh gazoturbinnykh dvigatelei [The theory of blade machines for aircraft gas turbine engines]. Samara, Samarskii gosudarstvennyi aerokosmicheskii universitet Pub., 2001. 155 p.

2. Morgunov, Yu. A., Saushkin, B. P. Additivnye tekhnologii dlya aviakosmicheskoi tekhniki [Additive technologies for aerospace engineering]. Additivnye tekhnologii - Additive technologies, 2016, vol. 1, no. 1, pp. 30-38.

3. Adzhamskii, S. V., Kononenko, A. A., Podol'skii, R. V. Perspektivy primeneniya additivnykh tekhnologii $\mathrm{v}$ avia- $\mathrm{i}$ raketostroenii [Prospects for the application of additive technologies in aircraft and rocket engineering]. Aviacijno-kosmicna tehnika i tehnologia - Aerospace technic and technology, 2020, no. 7(167), pp. 59-65. DOI: 10.32620/aktt.2020.7.09.

4. Kaynak, Y., Tascioglu, E. Post-processing effects on the surface characteristics of Inconel 718 alloy fabricated by selective laser melting additive manufacturing. Progress Additive Manufacturing, 2020, vol. 5, pp. 221-234. DOI: 10.1007/s40964-019-00099-1.

5. Rudawska, Anna. Surface Treatment in Bonding Technology. Faculty of Mechanical Engineering, Lublin University of Technology, Lublin, Poland, 2019. 284 p. DOI: 10.1016/C2018-0-01281-5.

6. Andreas, W. Hydroblasting and Coating of Steel Structures. Elsevier Science, 2003. 205 p. DOI: 10.1016/B978-1-85617-395-7.X5000-8.

7. Liu, X., Kang, X., Zhao, W., Liang, W. Electrode feeding path searching for 5-axis EDM of integral shrouded blisks. Procedia CIRP, 2013, Iss. 6, pp. $107-$ 111.

8. Gorelov, V. A., Arshinov, S. V., Maksimov, Yu. V., Pini, B. E., Bekaev, A. A., Merzlikin, V. G., 
Vtorova, A. Yu. K voprosu vybora tekhnologii obrabotki slozhnoprofil'nykh izdelii (na primere lopatok monokoles gazoturbinnykh dvigatelei) [On the issue of choosing a technology for processing complex-profile products (for example, blades of mono-wheels of gas turbine engines)]. Izvestiya Mosk. gosud. tekhn. un-ta MAMI Publ., 2012, vol. 2, no. 2 (14), pp. 67-73.

9. Klocke, F., Holstena, M., Welling, D., Klink, A., Perez, R. Influence of Threshold Based Process Control on Sinking EDM of a High Aspect Ratio Geometry in a Gamma Titanium Aluminide. Procedia CIRP, 2015, Iss. 35, pp. 73-78. DOI: 10.1016/j.procir.2013.03.041.

10. Nozhnitskii, Yu. A., Fishgoit, A. V., Tkachenko, R. I., Teplova, S. V. Razrabotka i primenenie novykh metodov uprochneniya detalei GTD, osnovannykh na plasticheskom deformirovanii poverkhnostnykh sloev [Development and application of new methods of hardening of GTE parts based on plastic deformation of surface layers]. Vestnik dvigatelestroeniya - Bulletin of engine construction, 2006, no 2, pp. 816.

11. Sukhochev, G. A., Smol'yannikova, E. G., Kodentsev, S. N., Nebol'sin, D. M. Tekhnologii proizvoditel'nogo formirovaniya kombinirovannymi metodami poverkhnostei polostei i kanalov pod nanesenie zashchitnykh pokrytii [Technologies for productive formation by combined methods of surfaces of cavities and channels for applying protective coatings]. Uprochnyayushchie tekhnologii $i$ pokrytiya - Strengthening technologies and coatings, 2009, no. 11(59), pp. 4954.

12. Polyanskii, S. N., Butakov, S. V., Aleksandrov, V. A., Ol'kov, I. S. Obrabotka poverkhnosti struinymi metodami [Surface treatment by jet methods]. Agrarnyi vestnik Urala - Agrarian Bulletin of the Urals, 2015, no. 12(142), pp. 43-47.

13. Shpilev, V. V., Reshetnikov, M. K. Vliyanie faktorov gidroabrazivnoi rezki na sherokhovatost' obrabotannoi poverkhnosti, ee tverdost', oval'nost' i konusoobraznost' [Influence of water-jet cutting factors on the roughness of the processed surface, its hardness, ovality and taper]. Vestnik. Saratovskogo gosudarstvennogo tekhnicheskogo. Universiteta - Bulletin. Saratov State Technical. University, 2011, vol. 2, iss. 2, pp. 160-163.

14. Tarasov, V. A., Polukhin, A. N. Otsenka geometricheskikh parametrov formiruemoi poverkhnosti pri gidroabrazivnoi obrabotke [Assessment of geometric parameters of the formed surface during hydroabrasive treatment]. Vestnik MGTU im. N. E. Baumana. Ser. «Mashinostroenie» - Bulletin of MSTU im. N.E.Bauman. Ser. "Mechanical Engineering", 2012, no. 1, pp. 107-116.

15. Gorbatov, I. V., Orlov, Yu. A., Antyufev, V. A., Tel'gerekova, T. V., Orlova, N. Yu. Opredelenie geometricheskoi tochnosti i sherokhovatosti poverkhnosti malogabaritnykh detalei kruglogo i kvadratnogo secheniya, poluchaemykh $\mathrm{v}$ zavisimosti ot raspolozheniya $\mathrm{v}$ rabochem prostranstve printera po tekhnologii selektivnogo lazernogo plavleniya iz stali marki 12X18H10T [Determination of geometric accuracy and surface roughness of small-sized parts of round and square cross-section, obtained depending on the location in the working space of the printer using the technology of selective laser melting from steel grade 12X18H10T]. Vestn. Kontserna VKO «Almaz - Antei», Moscow, 2019, no. 1, pp. 59-67.

Надійшла до редакиії 16.05.2021, розглянуто на редколегії 09.08.2021

\section{ВЫБОР ОПТИМАЛЬНЫХ МЕТОДОВ ЧИСТОВОЙ ОБРАБОТКИ ЛОПАТОК ЗАКРЫТЫХ МОНОКОЛЕС ТУРБОНАСОСНЫХ АГРЕГАТОВ, ПОЛУЧЕННЫХ АДДИТИВНЫМ МЕТОДОМ ПРЯМОГО ЛАЗЕРНОГО СПЕКАНИЯ ПОРОШКА}

\section{Ю. А. Шашко, А. В. Кулик, Р. Ф. Максимчук, А. Ф. Санин}

Создание сложных конструкционных элементов летательных аппаратов с использованием является перспективным и получает широкое применение, поскольку такие элементы имеют ряд конструктивных и технологических преимуществ по сравнению с изготовлением деталей по классическим технологиям. Однако оно требует решения ряда научно-технических задач для получения изделий высокой точности и шероховатости, разработку технологического процесса, отработки режимов обработки, а иногда и разработки новой конструкции изделий. Для развития технологий в современном ракетостроении, повышения качества и точности производства турбин турбонасосных агрегатов важной задачей является поиск новых и совершенствование существующих технологических решений для изготовления подобных деталей с высоким качеством поверхности. Целью работы был анализ существующих методов обработки деталей турбонасосных агрегатов со сложной геометрией и выбор наиболее технологичного для дальнейшего использования в технологических процессах. Задачей данной статьи является аналитический обзор существующих методов обработки поверхности деталей ответственного назначения и выбор наиболее технологичного при чистовой обработке лопаток турбины закрытого типа (с бандажом) с целью снижения шероховатости и улучшения 
качества рабочей поверхности. Объектом исследования является процесс обработки сегмента рабочего колеса турбины с никелевого сплава Inconel 718 (отечественный аналог - сплав ХН45МВТЮБР), что является ключевым элементом турбонасосного агрегата. Заготовка детали типа «моноколесо» турбины была изготовлена с помощью технологии 3D-печати. В итоге работы были выбраны оптимальный метод обработки, а именно - технологию сухого электрохимического полирования DryLyte, что имеет довольно значительные преимущества по сравнению с алогичными методами. Данный метод прошел экспериментальную отработку и активно внедряется за рубежом. Для внедрения данной технологии DryLyte необходимо провести дополнительные эксперименты по чистовой отделке внутренних каналов небольшого размера (24 мм) на примере межлопаточных каналов турбин, что позволит в полной мере оценить возможности технологии.

Ключевые слова: технологичность; турбонасосный агрегат; моноколесо; аддитивные технологии; SLM; качество; шероховатость; лопатки.

\title{
ELECTION OF OPTIMAL METHODS FOR CLEANING BLADES OF CLOSED MONOWHEELS OF TURBOPUMP UNITS OBTAINED BY THE ADDITIVE METHOD OF DIRECT LASER POWDER SINTERING
}

\author{
Yu. Shashko, A. Kulik, R. Maksimchuk, A. Sanin
}

The creation of complex structural elements of aircraft using is promising and is widely used since such elements have several structural and technological advantages over the manufacture of parts using classical technologies. However, it requires the solution of several scientific and technical problems to obtain products of high accuracy and roughness, the development of a technological process, the development of processing modes, and sometimes the development of a new design of products. For the development of technologies in modern rocketry, improving the quality and accuracy of the production of turbines of turbopump units, an important task is to search for new and improve existing technological solutions for the manufacture of such parts with high surface quality. The work aimed to analyze the existing processing methods for parts of turbopump units with complex geometry and select the most technologically advanced one for further use in technological processes. The objective of this article is an analytical review of existing methods of surface treatment of critical parts and the selection of the most technologically advanced method for finishing the blades of a closed-type turbine (with a shroud) to reduce the roughness and improve the quality of the working surface. The object of the research is the process of machining a segment of a turbine impeller made of Inconel 718 nickel alloy (domestic analog - alloy HN45MVTJuBR), which is a key element of a turbopump unit. The blank part of the turbine monowheel type was made using 3D printing technology. As a result of the work, the optimal processing method was chosen, namely, the DryLyte dry electrochemical polishing technology, which has quite significant advantages in comparison with illogical methods. This method has been tested experimentally and is being actively implemented abroad. To introduce this DryLyte technology, it is necessary to carry out additional experiments on finishing the inner channels of small size (24 mm) using the example of interscapular channels of turbines, which will make it possible to fully assess the capabilities of the technology. blades.

Keywords: manufacturability; turbopump unit; monowheel; additive technologies; SLM; quality; roughness;

Шашко Юрій Анатолійович - аспірант кафедри технології виробництва, Дніпровський національний університет імені Олеся Гончара; Flight Control Propulsion, Дніпро, Україна.

Кулик Олексій Володимирович - канд. техн. наук, доц. каф. технології виробництва, Дніпровський національний університет ім. Олеся Гончара, Дніпро, Україна.

Максимчук Роман Федосійович - інженер конструктор Flight Control Propulsion, Дніпро, Україна.

Санін Анатолій Федорович - д-р техн. наук, проф., зав. каф. технології виробництва, Дніпровський національний університет імені Олеся Гончара, Дніпро, Україна.

Yurii Shashko - PhD Student, Department of Production Technology, Oles Honchar Dnipro National University; Flight Control Propulsion, Dnipro, Ukraine,

e-mail: rockefeller260893@gmail.com, ORCID: 0000-0001-6962-440X.

Oleksiy Kulyk - candidate of technical sciences, Associate Professor of Production Technology Organization, Dnieper National University Oles Honchar, Dnipro, Ukraine, e-mail: kulyk@ftf.dnu.edu.ua, ORCID: 0000-0002-2913-4462, Scopus Author ID: 35847695900.

Roman Maksimchuk - Design Engineer at Flight Control Propulsion, Dnipro, Ukraine.

Anatolii Sanin - Doctor of Technical Sciences, Professor, Head of the Department of Production Technology, Oles Honchar Dnipro National University, Dnipro, Ukraine,

e-mail: afedsa60@gmail.com, ORCID: 0000-0002-5614-3882, Scopus Author ID: 7005800076. 